\title{
Comparison of the immune-modulating activity of Rhizopus nigricans meal with micro-particulate $\beta$ glucan prepared from the cell wall of Saccharomyces cerevisiae
}

\author{
${ }^{1}$ Adewoyin, A.G., ${ }^{2}$ Oloke, J.K., ${ }^{3}$ Togun, V.A., and ${ }^{2}$ Majolagbe, O.N. \\ ${ }^{1}$ Department of Science Laboratory Technology, Faculty of Pure and Applied Sciences. \\ ladunmola@yahoo.com \\ ${ }^{2}$ Department of Pure and Applied Biology, Faculty of Pure \& Applied Sciences. \\ ${ }^{3}$ Department of Animal production and Health, Faculty of Agricultural Sciences. \\ Ladoke Akintola University of Technology, P.M.B. 4000, Ogbomoso, Oyo State. Nigeria.
}

\begin{abstract}
The immune modulating activity of Rhizopus nigricans meal, and micro- particulate $\beta$-glucan were investigated in Sprague-Dawley rats injected with sodium arsenite. The $R$. nigricans meal was incorporated into the experimental feed of the rats to substitute for $50 \%$ of the maize in the diet. Thirty 10-12 weeks old rats were distributed randomly into five groups of six rats each. The different groups of the rats were administered either with sodium arsenite alone, $R$ nigricans meal or micro-particulate $\beta$-glucan orally or intraperioneally. The duration of administration and treatment was 26 days. Sperm count, sperm motility and histological studies of organs were carried out. The results showed that sodium arsenite caused severe pathology of the liver, heart and kidney. Oral administration of $0.1 \mathrm{mg} \mathrm{Kg}^{-}$body weight of micro- particulate $\beta$-glucan significantly alleviated the deleterious effect of sodium arsentie on the rats while the alleviating effect of $R$. nigricans meal was not significant but resulted in a significant increase in the level of leutenizing hormone (LH) and follicle stimulating hormone (FSH).
\end{abstract}

Keywords: Micro-particulate $\beta$-glucan, Rhizopus nigricans meal, Sodium aresnite, Leutenizing hormone, Follicle stimulating hormone.

\section{INTRODUCTION}

In most developing countries the problem of providing enough food is related to the problem of energy supplies and population growth (Spitzer, 1992). The Nigerian livestock feed industry competes with other sectors for the consumption of conventional ingredients. This competition often pushes the prices of finished feed upward. The high cost of conventional feed ingredient in recent years necessitated the utilization of non-conventional feed resources in livestock production. The nonconventional feed resources in Nigeria comprise of agro-industry by-product such as cocoa, peel, leaf meal, kola nut pod meal, rice bran and wheat bran (Oladunjoye et al., 2003). These agro-industrial byproducts are of low protein and high crude fiber contents and these two factors limit their use in poultry and pig feeding (lyayi and Losel, 2001). It is possible to take advantage of the current advances in biotechnology to increase crop productivity and improve animal and human health. (Moo-Young, 1982).
The advent of biotechnology, specifically, fungal biotechnology with its inexpensive mode of application has been used as a tool for the effective conversion of these waste. It is imperative to enhance the nutritive value of these by-products through the breakdown of their non-starch polysaccharides. The use of microbial degrading enzymes from fungi to achieve this is possible and highly desirable (lyayi and Adeolu, 2004). Fermentation is one of the oldest and most economical methods of producing and preserving food (Steinkraus, 1992). There are many traditional beliefs about the medicinal properties of fermented food products. The fur ethnic group in Sudan strongly believe that the consumption of fermented foods protect them from disease (Mahitosh et al., 2003). Certain lactic acid bacteria (e.g. Lactobacillus acidophilus) and moulds have been found to produce antibiotics and boacteriocins (Wood and Hodge, 1985; Adams and Nicolaids, 1997; Matsusaki et al., 1997). Substances in fermented foods have been 
Agric. Biol. J. N. Am., 2010, 1(6): 1243-1248

found to have protective effect against the development of cancer (Frohilich, 1997).

Beta (1-3)-d-glucan is an integral cell wall constituent found in a variety of plants, bacteria and fungi. There is an extensive literature describing the immunemodulating effect of both water soluble and insoluble $\beta$-glucan, with macrophages as the principal target cells. (Reynolds et al., 1980; Di Luzio, 1983; Gallen et al., 1992 Cleary et al., 1999). $\beta$-glucans binds to glucan receptors on phagocytic cells (Czop and Kay, 1991; Brown and Gordon 2001) and cause these cells to become activated (Di Luzio, 1983). Challenges to a healthy immune system include poor nutrition, physical and / or mental stress, environment pollution, chronic lack of sleep, over work and advancing age.

Arsenic, a well known human carcinogen, is widely distributed in the environment as a toxicant in coal soil, drinking water and air (Wullstein and Snyder 1971). Arsenic, as trivalent arsenite $\left(\mathrm{AS}^{3+}\right)$ or pentavalent arsenite $\left(\mathrm{AS}^{5+}\right)$ is naturally occurring and ubiquitously present in the environment. Human are exposed to arsenic mainly through either oral or inhalation routes. Oral exposure occurs via consumption of contaminated water, food and drugs. The metal is therefore a great threat to public health due to exposure via inhalation in industrial areas and ingestion from food, agricultural product and portable water. (EPA 2004).

Exposure to arsenic is associated with metabolic disorders, hypertrophy of adrenal glands (Biswas et al., 1994) and anemia (Sarkar et al., 1992). A number of sulfhydryl containing proteins have been found to be altered by exposure to arsenite (Robert and Judd, 1986). Gonadal effects of arsenic were first evaluated in mice, then fishes (Shukla and Pandey, 1984; Shukla and Pandey, 1984; Shukla and Pandey, 1985). Previous investigations have reported that sodium arsenite, at doses of 5 and $6 \mathrm{mg} \mathrm{kg}^{-1}$ daily for 26 days has a suppressive influence on spermatogenesis, gonadotrophin and testosterone release in rats (Mahitosh et al., 2003).

Although arsenic compounds are detoxified in the body mostly as arsenic salts through faces and as arsenate in urine, the rate of excretion is generally slow and most of the arsenates remain unmethylated. In this regards $20-25 \%$ of inorganic arsenite usually remain unmethylated (Hopen Hanyan Rich et al., 1993). Toxicity is therefore believed to result from the unmethylated and tissue bound arsenicals (IARC,
1980). The use of immune modulators either as prophylaxis and/or part of a treatment regimen following exposure, may present a broad-spectrum approach to protect the public when exposed to a pathogenic challenge.

The present study was undertaken (1) to investigate the acceptability of the feed incorporated with the $R$. nigricans meal in order to reduce cost of animal feed and (2) to compare the immune modulatory effect of the $R$. nigricans meal with micro particulate $\beta$-glucan prepared from the cell wall of Saccharomyces cerevisiae.

\section{MATERIALS AND METHODS}

Animals: $\mathbf{3 0}$ male Sprague-Dawley rats used for this experiment were obtained from the animal house of Physiology Department in the University of Ibadan, Oyo State and allowed to acclimatize to laboratory conditions for a period of two weeks. They were distributed into 5 groups and kept in a temperature of $\left(20-21^{\circ} \mathrm{C}\right)$ and light controlled (12 h light: $12 \mathrm{~h}$ dark cycle) room with free access to food and water.

Preparation of micro-particulate $\beta$-glucan from $S$. cerevisiae: The micro-particulate $\beta$-glucan used for this study was prepared as previously described by Hunter et al., (2002). Active dry yeast was added to $0.1 \mathrm{~mol}^{-1}$ of $\mathrm{NaOH}$, stirred for 30 minutes at $60^{\circ} \mathrm{C}$ and heated to $115^{\circ} \mathrm{C}$ at 8.5 psi for 45 minutes. The mixture was then allowed to settle for 72 hours. The sediment was re-suspended and washed in distilled water. The alkali insoluble solids were mixed with $0.1 \mathrm{ml}^{-1}$ acetic acid and heated to $85^{\circ} \mathrm{C}$ for 1 hour, and allowed to settle at $38^{\circ} \mathrm{C}$. The acid insoluble solids were drawn off, centrifuged and the resultant compacted solid material was then mixed with $3 \%$ $\mathrm{H}_{2} \mathrm{O}_{2}$ and refrigerated for 3 hours with periodic mixing. The material was then centrifuged again and the pellet washed twice with distilled water, followed by two washings in $100 \%$ acetone. The harvested solid material was dispersed on drying trays and dried under vacuum at $38^{\circ} \mathrm{C}$ for 2 hours in the presence of $\mathrm{Ca}_{2} \mathrm{SO}_{4}$ and further dried overnight under vacuum at room temperature. The solid microparticulate thus obtained was dissolved in sterile distilled water before being administered to the rats.

Preparation of the Rhizopus nigricans meal: About $850 \mathrm{~g}$ of rice bran was fermented (solid state fermentation) in each fermentation tray after steaming for 4 hours. This was inoculated with jars of mass-produced $R$. nigricans after adjusting the 
moisture content of the steamed rice bran to $25 \%$. The fermentation was carried out for 14 days at room temperature after which the mycelia mat was scooped out and sun-dried. The Rhizopus meal obtained was stored in sacs until needed.

Preparation of the Experimental Feed: The experimental feed was prepared by substituting $50 \%$ of the maize in the commercial diet with $50 \%$ of the Rhizopus meal (lyayi and Aderolu, 2004).

Sodium arsenite: $\left(\mathrm{NaAsO}_{2} ;\right.$ Loba Chem, Co.Bombay, India) was dissolved in Physiolgical Saline before being administered to the rats.

Administration: The rats were distributed into 5 groups and administered daily as follows:

Group 1 rats were administered with $0.2 \mathrm{ml}$ of $0.1 \mathrm{mg}$ $\mathrm{Kg}^{-1}$ body weight of micro particulate $\beta$-glucan by gavage, $0.2 \mathrm{ml}$ of $6 \mathrm{mg} \mathrm{Kg}^{-1}$ body weight of sodium arsenite intraperitoneally and fed with commercial pellet.

Group II rats were administered with $0.2 \mathrm{ml}$ of 0.94 $\mathrm{Kg}^{-1}$ body weight of vitamin $\mathrm{E}, 0.2 \mathrm{ml}$ of $6 \mathrm{mg} \mathrm{Kg}^{-1}$ body weight of sodium arsenite intraperioneally and fed with commercial pellet.

Group III rats were administrated with $0.2 \mathrm{ml}$ of $6 \mathrm{mg}$ $\mathrm{Kg}^{-1}$ body weight of sodium arsenite intraperitioneally and fed with feed incorporated with Rhizopus meal.

Group IV rats were administered with $0.2 \mathrm{ml}$ of $6 \mathrm{mg}$ $\mathrm{Kg}^{-1}$ body weight of sodium arsenite intraperitoneally and fed with commercial pellet.

Group V rats were administered with $0.2 \mathrm{ml}$ of physiological saline intraperitoneally and fed with commercial pellet. This served as the control group. The duration for administration was 26 days (Mahitosh et al., 2003).

Table 3: Ameloration of the effect of sodium arsenite on LH FSH and testosterone by microparticulate $\beta$-glucan vitamin e and rhizopus meal.

\begin{tabular}{|l|c|c|c|}
\hline Group & Leutenizing hormone $\mathbf{~ L H ~} \mathbf{~} / \mathbf{\mu} / \mathbf{m l}$ & Follicle stimulating hormone FSH $\mathbf{~} / \mathbf{\mu} / \mathbf{m l}$ & Sperm motility \\
\hline I & $2.5 \pm 0.00^{\mathrm{b}}$ & $5.25 \pm 3.18^{\mathrm{a}}$ & $2.45 \pm 2.19^{\mathrm{a}}$ \\
\hline II & $2.75 \pm 0.35^{\mathrm{ba}}$ & $3.25 \pm 0.35^{\mathrm{b}}$ & $0.65 \pm 0.21^{\mathrm{b}}$ \\
\hline III & $2.15 \pm 1.77^{\mathrm{a}}$ & $3.75 \pm 1.77^{\mathrm{ba}}$ & $0.60 \pm 0.85^{\mathrm{b}}$ \\
\hline IV & $2.15 \pm 0.49^{\mathrm{b}}$ & $2.50 \pm 0.00^{\mathrm{b}}$ & $0.70 \pm 0.42^{\mathrm{b}}$ \\
\hline V & $3.75 \pm 1.77^{\mathrm{a}}$ & $2.25 \pm 0.35^{\mathrm{b}}$ & $0.85 \pm 0.21^{\mathrm{b}}$ \\
\hline
\end{tabular}

Sacrifice of animals: On the $27^{\text {th }}$ day, animal were sacrificed following ethical procedures, blood samples were collected by cardiac puncture. Heparinized plasma was prepared and stored until hormone assay were carried out. Heart, kidney, liver and testis were also collected weighed and taken for histological study.

Quantitative results obtained were evaluated for statistical differences by analysis of variance (ANOVA) procedure and then least significant difference procedure (LSD) was used to compare data from groups of rats.

\section{RESULTS}

Table 1: Effect of vitamin E, micro-paticulate $\beta$-glucan and Rhizopus meal on weight of organs of rats injected with sodium arsenite

\begin{tabular}{|c|c|c|c|c|}
\hline GROUP & $\begin{array}{c}\text { LIVER } \\
\text { (g) }\end{array}$ & $\begin{array}{c}\text { KIDNEY } \\
\text { (g) }\end{array}$ & $\begin{array}{c}\text { HEART } \\
\text { (g) }\end{array}$ & $\begin{array}{c}\text { TESTES } \\
(\mathrm{g})\end{array}$ \\
\hline $\mathrm{I}$ & $\begin{array}{r}8.01 \\
\mathbf{\pm 1 . 0 1 ^ { a }} \\
\end{array}$ & $\begin{array}{c}1.72 \\
\pm 0.12^{a} \\
\end{array}$ & $\begin{array}{c}0.83 \\
\pm 0.11^{d} \\
\end{array}$ & $\begin{array}{c}1.70 \\
\pm 0.15^{\mathrm{b}} \\
\end{array}$ \\
\hline II & $\begin{array}{c}6.84 \\
\pm 0.83^{\text {ba }} \\
\end{array}$ & $\begin{array}{r}1.32 \\
\pm 0.13^{\mathrm{cb}} \\
\end{array}$ & $\begin{array}{c}0.68 \pm 0- \\
05^{\mathrm{cb}}\end{array}$ & $\begin{array}{r}2.01 \\
\pm 0.10^{a} \\
\end{array}$ \\
\hline III & $\begin{array}{c}5.71 \\
\pm 1.11^{\mathrm{b}} \\
\end{array}$ & $\begin{array}{c}1.18 \\
\pm 0.19^{c} \\
\end{array}$ & $\begin{array}{c}0.62 \\
\pm 0.08^{\mathrm{c}}\end{array}$ & $\begin{array}{c}1.23 \\
\pm 0.20^{d}\end{array}$ \\
\hline IV & $\begin{array}{c}5.71 \\
\pm 0.52^{\mathrm{b}} \\
\end{array}$ & $\begin{array}{c}1.22 \\
\pm 0.11^{\mathrm{cb}}\end{array}$ & $\begin{array}{c}0.64 \\
\pm 0.05^{\mathrm{c}}\end{array}$ & $\begin{array}{c}1.35 \\
\pm 0.04^{\text {cd }}\end{array}$ \\
\hline V & $\begin{array}{r}6.50 \\
\pm 0.20^{b} \\
\end{array}$ & $\begin{array}{r}1.35 \\
\pm 0.12^{b} \\
\end{array}$ & $\begin{array}{c}0.71 \\
\pm 0.09^{b} \\
\end{array}$ & $\begin{array}{c}1.53 \\
\pm 0.12^{\mathrm{bc}} \\
\end{array}$ \\
\hline
\end{tabular}

Table 2: Amelioration of the effect of sodium asenite on sperm count and sperm motility by microparticulate $\beta$ glucan, vitamin E and Rhizopus meal

\begin{tabular}{|c|c|c|}
\hline Group & $\begin{array}{c}\text { Sperm count x } \\
\left(10^{6}\right) \mathbf{~} / \mathbf{m l}\end{array}$ & Sperm motility \\
\hline I & $31.35 \pm 1.68^{\mathrm{b}}$ & $72.55 \pm 7.80^{\mathrm{ab}}$ \\
\hline II & $71.39 \pm 5.95^{\mathrm{a}}$ & $40.95 \pm 16.26^{\mathrm{C}}$ \\
\hline III & $14.25 \pm 1.28^{\mathrm{C}}$ & $52.62 \pm 19.05^{\mathrm{bC}}$ \\
\hline IV & $29.40 \pm 4.24^{\mathrm{b}}$ & $40.62 \pm 5.82^{\mathrm{C}}$ \\
\hline $\mathrm{V}$ & $30.20 \pm 1.61^{\mathrm{b}}$ & $86.44 \pm 3.80^{\mathrm{a}}$ \\
\hline
\end{tabular}


Table 4: Alleviation of the effect of sodium arsenite on organs by microparticulate $\beta$ - glucan, vitamin $E$ and rhizopus meal.

\begin{tabular}{|l|l|l|l|}
\hline Group & Heart & Liver & Kidney \\
\hline I & Mild le lesions & Mild lesions & No visible lesions \\
\hline II & No visible lesions & Mild lesions & No visible lesion \\
\hline III & Mild le lesions & Moderate lesions & No visible lesion \\
\hline IV & & & \\
\hline V & Marked lesions & Marked lesions & Marked lesions \\
\hline
\end{tabular}

$$
\text { Key }
$$

I- Sodium arsenite + microparticulate beta glucan + commercial feed

II- Sodium aresenite + vitamin E + commercial feed

III- Sodium aresenite + feed formulated with Rhzopus meal

IV- Sodium aresenite + commercial feed

V-Normal saline + commercial feed

\section{DISCUSSION}

Results show that treatment with a daily dose of 0.2 $\mathrm{ml}$ of $6 \mathrm{mg} \mathrm{Kg}-1$ body weight of sodium arsenite caused significant deleterious effects on the sperm parameters (Sperm count and Sperm motility), sex hormones and the organs and this is in agreement with earlier investigations on the effects of sodium arsenite Shukla and Pandey, 1984; Shukla and Pandey, 1985 ; Mahitosh et al., 2003).

The mean weight of the organs (liver, kidney, heart and testes) collected after sacrificing the rats shows that apart from the group administered microparticulate $\beta$ - glucan that was significantly different (Table 1); there was no significant difference in the other groups. This also indicates that the rats in the group that was given the Rhizopus meal were able to metabolize the feed stuff of their diet despite injection with sodium arsenite thereby reducing the cost of feeding.

The deleterious effect of sodium arsenite on the sperm count and sperm motility was alleviated significantly in the group given vitamin $E$ (Table 2).This positive effect of vitamin $E$ on sperm parameters is in agreement with earlier reports (Dokunkin and Alyakaev, 1986; Velasquez-Pereira et al., 1998; Togun et al., 2005) It is also evident from the results obtained in this study that the microparticulate $\beta$ - glucan has alleviated part of the deleterious effect of sodium arsenite on the sperm count since the mean sperm count value and mean sperm motility values were not significantly different from that of the control group. The deleterious effect was not significantly alleviated in the group fed with feed incorporated with Rhizopus meal as indicated by the low values of the sperm count.

The deleterious effect of sodium arsenite on the level of LH (Table 3) has probably prevented the interstitial cells from stimulating them to synthesize and secrete testosterone which is essential for sperm production. The mean value of the group given micro-particulate $\beta$ - glucan and the group given feed formulated with Rhizopus meal were not significantly different from each other and significantly from the control group.

The histopathology of the organs showed that sodium arsenite caused severe hemorrhages, necrosis and congestion of the organs which resulted in severe lesions. There were only mild lesions in the organs of the rats treated with vitamin $\mathrm{E}$ and micro-particulate $\beta$-glucan. The lesions were moderate in the group fed with feed formulated with Rhizopus meal.

In all, the immune modulating activities of the different test agents used in this work as indicated by the amelioration of the deleterious effect of sodium arsenite was highest in vitamin $E$ followed by the micro-particulate $\beta$-glucan and then the least was the Rhizopus meal.

From this work, it is reported that substitution of $50 \%$ maize in the commercial feed with Rhizopus meal had no adverse effect on the animals as indicated in the weight of the weight of the organs. It was also observed that the administration of micro-particulate $\beta$-glucan prepared from the cell wall of S.cerevisiae enhanced the degree of modulating capacity against sodium arsenite clastogenicity. And since exposure to sodium arsenite in the environment via inhalation in industrial areas and ingestion from food agricultural products and water might be inevitable because of its extensive use, there is the need for readily available 
protection against its deleterious effects. This is in agreement with the suggestion of earlier researchers that $\beta$-glucan could be considered as an effective way of rebuilding the immune system and preventing infection following chemotherapy and radiation in cancer treatment. It was reported to work as a free radical scavenger (anti-oxidant) and may protect the macrophages from damage by radiation, toxin, heavy metals and free radicals.

\section{REFERENCES}

Adams, M.R. and Nicolaidses, L. (1997) Review of the Sensitivity of Different Food borne pathogens to Fermentation, Food Control, UK .

Biswas, N.M;Roy, Chowdhury G; Sarkar, M.(1994) Effect of sodium arsenite on adrenocortical Activities in male rats dose-duration dependent responses. Med Sci Res 23:153-154.

Brown, G.D. and Gordon, S.A. (2001) New Receptor for $\beta$ glucans. Nature 413, 36-37.

Cleary, J.A, Kelly, G.E. and Husband, A.J. (1999) The Effect of Molecular weight and Beta-1,6- Linkages On priming of Macrophage Function in Mice by $(1,3)$ Beta-D-Glucan. Immune and Cell Biol. 77, 395-403.

Czop, J.K. and Kay, J (1991).Isolation and Characterisation of $\beta$-Glucan Receptors on Human Mononuclear Phargocytes, J. Expt. Med. 8 1511-1520.

DiLuzio, N.R. (1983).Immunopharmcology of Glucans: A Broad Spectrum Enhancer of Host Defense Mechanisms. Trend in Pharmacol. Sc. 4:344-347.

Di Luzio, N.R., McNaMee, R. b., Williams, D.L., Gilbert, K.M. and Spanjers, M.A. (1980).Glucan induced inhibition of tumor growth and enhancement of survival in a variety of transplantable and spontaneous murine tumor models. Adv. Exp. Med. Biol. 121 A: 269:290

Dirar, H., (1992). Sudan's Fermented Food Heritage in "Application of Biotechnology to Traditional Fermented Food". National Academy press.

Dokunkin, A.P. and Alyakaev, A.M. (1986).Vitamin E in Rations of Rams. Ortsevodsvo 37-39.

Frohlich, R.H., Kunze, M and Kiefer, I (1997).Cancer Preventive Impact of Naturally Occurring, Nonnutritive Constituents in Food, Acta Medical Austrica, Austrial.

Gallin, E.K.; Green, S.W. and Pathchen, M.L. (1992).Comparative Effects of Particulate and Soluble Glucan on Macrophages of $\mathrm{C} 3 \mathrm{H} / \mathrm{HeN}$ and $\mathrm{C} 3 \mathrm{H} / \mathrm{HeJ}$ Mice. International Journal of imunopharmacology 14:173-183.

Hopen Hanyan Rich, C.; Smith A.H. and Goeden, H.M. (1993). Human Studies Do Not Support the
Methylation Threshold Hypothesis for the Toxicity of Inorganic Arsenic. Environ Res. 60:161-177.

Hunter, K. Gault, R.A. and Berna, M.D. (2002).Preparation of Microparticulate $\beta$-Glucan from Saccharomyces cerevisiae for use in Immune Potentiation. Letters in Applied Microbiology. 35:4; 267-271.

IARC. (1980).Monographs on the Evaluation of the Carcinogenic Risk of Chemical to Human IARC Suppl. 4.

lyayi, E.A. (2004).Changes in the Cellulose, Sugar and Crude Protein of Agr-industrial by-products fermented with Aspergillus niger, Aspergillus flavus, and Penicillium sp. Afri. J. Biotchnol. 3(3) pp 186-188.

Iyayi, E.A. and Aderolu, Z.A. (2004).Enhancement of the Feeding Value of Some Agro-industrial by- products For laying after their solid state fermentation with Trichoderma viride. Afr. J. Biothecnol. 3 (3). Pp 182185.

Iyayi, E.A., Losel, D.M.. (2001).Changes in Carbohydrate Fractions of Cassava Peel Following Fungal Solid Fermentation J. Food Technol. Afr. 6(3) 101-103.

Mahitosh Sarkar Gargi Ray Chaudhuri, Aloke Chatopadhyay, Narendra Mohen Biswas. (2003).Effect of Spermatogenesis, Plasma Gonadotropins and Testosterone in Rats. As.J.Adrol. Mar; 5:27-31

Matsusaki, $\mathrm{H}$; Sonomoto, $\mathrm{K}$ and Ishizaki, $\mathrm{A}$. (1997).Bacteriocins, Growth Inhibitory Substances of Lactic Acid Bacteria. Shibutsu Kogaku Kaish. J. Society for Ferment. And Bioengin. Japan.

Moo-Young, M. (1982).in proc. Symp. On Bioconversion Process, UNIDO Seminar, Nov Yugoslavia, P.S., Msinae Printers B 54: pp 243-254.

Oladunjoye, I.O, ; Amao. O.A; Eniola, I.A. Aderinola, O.A,; Olayeni, T.B. and Ojedapo L.O. (2003). Potential Of Cowpea (Vigna umguiculata) Testa Meal as a Subtitute of maize in the diet of Rabbit. Science Focus 3: 6-10.

Reynolds J.A,; Kastello, M.D,; Harington, D.G,; Crabbs, C.J,; Jemski, J. V,; Scott, G.H. and Diluzio, N.R. (1980). Glucan induced Enhancement of Host Resistance to Selected Infectious Diseases infection and immunity. 30:51-57.

Robert, E.M; Judd, O.N.(1986). Water and soil pollutants. In : Klassen, C.D.; Ambur, M.D. ; J Douli, editors, Toxicology. The basic science of poison. $3^{\text {rd }}$ edition New York Macmillan Publishing Company, p 825.

Sarkar, M.; Ghosh,D.; Biswas, H.M.(1992). Effects of sodium arsenite on haematology in Male albino rats. Ind J Physiol Allied Sc. 46: 116-120.

Shukla, J.P; Pandey, K. (1984). Impaired spermatogenesis in arsenic treated fresh water fish Colisa fasciatus (BI \& Sch). Toxicol Lett 21: 191-195. 
Shukla, J.P; Pandey, K. (1984). Arsenic induced cellular and biochemical changes during the Testicular cycle of a fresh water perch. Colisa fasciatus (BI \& Sch). Cell Mol Biol 30: 227-231.

Shukla, J.P; Pandey, K.(1985). Toxicity and long term effect of arsenic on the gonadal protein Metabolism in a tropical fresh water fish. Colisa fasciatus (BI \& Sch) Acta Hydrochem Hydrbiol 13: 127-131

Spitzer, R.R. (1978). In Proc. $171^{\text {st }}$ ACS National Meeting New York pp. 4-8, June.

Steinkraus, K. (1992).Lactic Acid Fermentation in Application of Biotechnology to Traditional Fermented Foods', National Academy Press, USA.

Togun, V.A.; Oyadeyi, A.S,; Oloke, J.K. and Oyewopo, A.O. (2005).Effect of Sodium Arsenite with or without Vitamin $E$ on epididymal Sperm Motility and Concentration in Sprague-Dawley Rat. Proc. $39^{\text {th }}$ Conference of the Agricultural Society of Nigeria, Benin.
U.S. Environmental Protection Agency (EPA) (1984). Health Assessment Document for inorganic Arsenic EPA 600/8-83/021F. Clicinat; O.H.U.S EPA

Velasquez - Pereira J., Chenoweth McDowell, I.R., Risco, C.A. Staples, C. A., Prich Martin, F.G., Galhoun, M.L., Williams S.N. and Wikinson, N.S. (1998).Reproductive Effect of Feed Gossypol and Vitamin E to Bulls. J. Amin. Sci. 76 (11) 2894-2904.

Wood, B.J.B and Hodge, M.H. (1985).Yeast-Lactic Acid Bacteria Interactions and their Contribution of Fermented Foodstufs in 'Microbiology of Fermented foods'. Edited by Wood, B.J.B., Elsevier Applied Science Publishers.

Wullsten, L.H. and Snyder, K (1971).Arsenic Pollutant in the Ecosystem. Proc. Of the Second International Clean Air Congress. Washington D.C. National Society for Clean Air, pp. 295-301. 